\title{
ДЕСТРУКТИВНИЙ ВПЛИВ БОЙОВОГО СТРЕСУ НА ЕМОЦІЙНУ СФЕРУ ОСОБИСТОСТІ ВІЙСЬКОВОГО
}

\author{
Лящ Оксана
}

Вінницький державний педагогічний університет імені

М. Коцюбинського, м. Вінниця, Україна

Oksanalyash7@gmail.com

ORCID ID: 0000-0002-1317-4398

\section{Яцюк Марія}

Комунальний заклад вищої освіти «Вінницька академія безперервної освіти», м. Вінниця, Україна

mvalerkovna@gmail.com

ORCID ID: 0000-0002-2393-9964

Mema. Мета статті полягає у встановленні деструктивного впливу бойового стресу на емоційну сферу військового.

Meтоди. Відповідно до мети дослідження використаний контент-аналіз бесіди, методика на визначення рівня стресу Л. Рідера, PHQ-9 шкала самооцінки депресії, шкала тривожності Тейлор, методи математичної статистики.

Результати. В статті розглянуто проблему впливу бойового стресу на емоційну сферу військових. Зазначено, що основною реакцією військовослужбовця на бойові події $є$ бойовий стрес, відмінною особливістю якого є наявність стрес-факторів бойової обстановки. Уточнено, що бойовий стрес розуміється як багаторівневий процес адаптаційної активності людського організму в умовах бойової обстановки, що супроводжується актуалізацією механізмів реактивної саморегуляції $\mathrm{i}$ закріпленням специфічних пристосувальних психофізіологічних змін. Результати дослідження вказують на те, що негативні психічні стани, які виникають у військовослужбовців у період виконання небезпечних для здоров'я і життя завдань, після повернення з зони бойових дій проявляються у загостренні почуття честі, гідності та справедливості, зростанні реакцій некерованої агресивності, тривоги, конфліктності, що різко ускладнюють процес реадаптації демобілізованих військових та безумовно вимагають проведення психологічної корекції. Отримані результати дослідження свідчать про те, що тривалі психотравмуючі фактори бойової обстановки деструктивно впливають на емоційну сферу військових, а в силу особистісних особливостей, у багатьох демобілізованих

ISSN 2308-3743 (Online), ISSN 2227-1376 (Print)

(C) Лящ О., Яцюк М., 2021. Ця стаття відкритого доступу на умовах CC BY-NC 4.0 
порушується регуляція поведінки, а також морально-етична та когнітивна сфери.

Висновки. Встановлено, що у формуванні деструктивних наслідків вагому роль відіграють конфліктні переживання в системі цінностей та смислів професійної діяльності військовослужбовця, які актуалізуються в ситуації загрози життю та здоров'ю особистості. За допомогою точної оцінки та прогнозу впливу бойового стресу на особистість військового з'являється можливість командирам частин та підрозділів спрогнозувати виникнення деструктивних психічних станів, а також динаміки поведінки особового складу в екстремальних умовах та адекватно реагувати на зміни в обстановці.

Ключові слова: деструктивні психічні стани, військовослужбовці, бойовий стрес, адаптація, здоров’я особистості.

\section{Liashch Oksana, Yatsiuk Mariia. Destructive effect of combat stress on the emotional sphere of the military personality.}

Purpose. The purpose of the article is to establish the destructive effects of combat stress on the emotional sphere of the military.

Methods. In accordance with the purpose of the study used content analysis of the conversation, methods for determining the level of stress L. Reeder, PHQ-9 scale of self-assessment of depression, Taylor anxiety scale, methods of mathematical statistics.

Results. The article considers the problem of the impact of combat stress on the emotional sphere of the military. It is noted that the main reaction of a serviceman to combat events is combat stress, the difference of which is the presence of stress factors in the combat situation. It is specified that combat stress is understood as a multilevel process of adaptive activity of the human body in a combat situation, accompanied by the actualization of the mechanisms of reactive self-regulation and the consolidation of specific adaptive psychophysiological changes. The results of the study indicate that the negative mental states that occur in servicemen during the performance of tasks dangerous to health and life, when returning from combat, are manifested in an exacerbation of honor, dignity and justice, increased reactions of uncontrolled aggression, anxiety, conflicts that dramatically complicate the process of readaptation of demobilized servicemen and certainly require psychological correction. The results of the study indicate that long-term traumatic factors of the combat situation have a destructive effect on the emotional sphere of the military, and due to personal characteristics, many demobilized violate the regulation of behavior, as well as moral, ethical and cognitive spheres.

Conclusions. It is established that in the formation of destructive consequences an important role is played by conflicting experiences in the system of values and meanings of the professional activity of the serviceman, which are actualized in the situation of threat to life and health of the individual. Accurate assessment and prediction of the impact of combat stress on the personality of the military makes it possible for unit and unit commanders to predict the occurrence of destructive mental states, as well as the dynamics of personnel behavior in extreme conditions and 
respond adequately to changes in the situation.

Keywords: destructive mental states, servicemen, combat stress, adaptation, personal health.

Лящ Оксана, Яцюк Мария. Деструктивное влияние боевого стресса на эмоциональную сферу личности военного.

Цель. Цель статьи заключается в установлении деструктивного влияния боевого стресса на эмоциональную сферу военного.

Memoды. В целях исследования использован контент-анализ беседы, методика на определение уровня стресса Л. Ридера, PHQ-9 шкала самооценки депрессии, шкала тревожности Тейлора, методы математической статистики.

Pезультаты. В статье рассмотрена проблема влияния боевого стресса на эмоциональную сферу военных. Указано, что основной реакцией военнослужащего на боевые события являются боевой стресс, отменной особенностью которого является наличие стресс-факторов боевой обстановки. Уточнено, что боевой стресс понимается как многоуровневый процесс адаптационной активности человеческого организма в условиях боевой обстановки, сопровождается актуализацией механизмов реактивной саморегуляции и закреплением специфических приспособительных психофизиологических изменений. Результаты исследования указывают на то, что негативные психические состояния, возникающие у военнослужащих в период исполнения опасных для здоровья и жизни задач, по возвращении из зоны боевых действий проявляются в обострении чувства чести, достоинства и справедливости, росте реакций неуправляемой агрессивности, тревоги, конфликтности, резко усложняют процесс реадаптации демобилизованных военных и безусловно требуют проведения психологической коррекции. Полученные результаты исследования свидетельствуют о том, что длительные психотравмирующие факторы боевой обстановки деструктивно влияют на эмоциональную сферу военных, а в силу личностных особенностей, во многих демобилизованных нарушается регуляция поведения, а также моральноэтическая и когнитивная сферы.

Выводы. Установлено, что в формировании деструктивных последствий важную роль играют конфликтные переживания в системе ценностей и смыслов профессиональной деятельности военнослужащего, актуализируются в ситуации угрозы жизни и здоровью личности. С помощью точной оценки и прогноза воздействия боевого стресса на личность военного появляется возможность командирам частей и подразделений спрогнозировать возникновение деструктивных психических состояний, а также динамики поведения личного состава в экстремальных условиях и адекватно реагировать на изменения в обстановке.

Ключевые слова: деструктивные психические состояния, военнослужащие, боевой стресс, адаптация, здоровье личности. 
Вступ. Бойові дії на сході нашої держави тривають щодня, про що інформують засоби масової інформації. Боротьба за територіальну недоторканість України не проходить без втрат. Національна гвардія втратила загиблими 230 воїнів, 914 нацгвардійців отримали поранення, а $13-\epsilon$ зниклими безвісти. За таких умов неминучим $\epsilon$ бойовий стрес військових, який з'являється під дією потужних зовнішніх i внутрішніх стрес-факторів екстремальної діяльності. Небезпечні умови виконання професійних завдань, постійна загроза життю військового негативно впливають на стан його здоров'я, знижують ефективність діяльності та можуть призводити до іiі зриву.

Бойовий стрес може викликати гострі психологічні реакції на стрес-фактори, так і впливати на розвиток важких стресових розладів (Блінов, 2017). Як показують клінічні дослідження, прояви стресових розладів військових, учасників бойових дій, характеризуються високим рівнем тривожності, агресивності, конфліктності суб'єкта, зниженням працездатності, поширенням дезадаптації, виникненням депресивних станів, проявів суїцидальної поведінки, алкоголізму, наркоманії, асоціальної поведінки (Литвинцев, Снедков, Резник, 2005). У зв’язку зі значною актуальністю проблеми бойового стресу та його наслідків, як для комбатів, так і для суспільства, вона потребує уважного вивчення причин та механізмів впливу.

Аналіз виконаних досліджень показав, що дослідники недостатню увагу приділили характеристиці деструктивних наслідків впливу бойового стресу на емоційну сферу військових (Осьодло, 2013, 2017).

Мета статті полягає у встановленні впливу бойового стресу на формування деструктивних емоційних станів військових.

Основною реакцією військовослужбовця на бойові події $\epsilon$ бойовий стрес, відмінною особливістю якого $\epsilon$ наявність стресфакторів бойової обстановки.

Ми розділяємо визначення О. Г. Караяні та I. В. Сиромятникова, які розглядають бойовий стрес як багаторівневий процес адаптаційної активності людського організму в умовах бойової обстановки, що супроводжується напругою механізмів саморегуляції і формуванням пристосувальної поведінки; механізм комплексної мобілізації організму для дій в небезпечних умовах. Бойовий стрес - це процес мобілізації всіх наявних можливостей організму, імунної, нервової, психічної систем для подолання небезпечної ситуації (Караяни, 2016). 
Ними також були виділені рівні бойового стресу: біохімічний (гормональні зміни); фізіологічний (зміни в об'ємі легенів, різкості і дальності зору, звуження артерій, а відтак збільшення тиску крові, перерозподіл кров'яних потоків, як наслідок збільшення енергопостачання та сили м'язів, виведення шлаків); психофізіологічний (зміни в реактивності симпатичної i парасимпатичної нервової систем); психологічний (звуження свідомості, концентрація на небезпеці, відчуття тривоги; зміни в мотивації діяльності); соціально-психологічний (діяльнісне опосередкування спілкування, його згорнутість, зниження етичного статусу) (Кравченко, 2017).

Також можна говорити про його специфічні форми: нетравматичний стрес; травматичний (бойова психічна травма); посттравматичний. Реактивні стани є типовими за умов бойового стресу у військових, що проявляються як тимчасові зворотні розлади психічної діяльності, які виникають як реакція у відповідь на вплив психічної травми. Бойовий стрес одночасно може бути i травматичним стресом, тоді він проявляється як бойова психічна травма (Shay, 2003).

Методи та процедура дослідження. Відповідно до мети дослідження використаний контент-аналіз бесіди, методика на визначення рівня стресу Л. Рідера, PHQ-9 шкала самооцінки депресії, шкала тривожності Тейлор, методи математичної статистики.

В експериментальному дослідженні взяли участь 82 військових, демобілізованих учасників ООС.

Обговорення результатів. Деструктивними наслідками дії бойових психотравмуючих чинників $є$ функціональні порушення в структурах ЦНС військових, вегетативних систем, наростання специфічної особистісної дисгармонії, готовність до психопатологічного синдромоутворення, порушення адаптивних механізмів організму, формування психосоматичних захворювань.

На першому етапі проведено психологічну бесіду, яка спрямована на з'ясування мотиваційного компоненту готовності військових співпрацювати $з$ працівниками психологічної служби. За результатами бесіди, за допомогою контент-аналізу, встановлено превалювання у військових мотивів утвердження почуттів честі та власної гідності, поваги та визнання як серед побратимів, так i в суспільстві. Відновлення власної психічної цілісності військові вбачають в 
успішній професійній реалізації у цивільному житті після залишення служби та набутті гідного соціального статусу в суспільстві.

Чимале значення для ефективної соціалізації після демобілізації військовослужбовці визначають за налагодженням та відновленням здорових взаємостосунків у сім'ї (Кудренко, Афанасенко, 2018). Адже в період виконання бойових завдань вони були дистанційовані від життя родин. У цей період їхні сім'ї переживали тривалий період рольових та ціннісних трансформацій. Чималих труднощів викликає відновлення подружніх взаємостосунків. Бойові дії та тривалі періоди розлуки змінюють як партнерів, так і самі сімейні ролі (Локтаєва, 2014). Дружина, за тривалої розлуки з чоловіком, звикає брати на себе головну відповідальність за виховання дітей, побут та вирішення основних проблем, у той час як чоловік, після повернення в сім'ю, потребує часу для відновлення власного авторитетного статусу в родині, крім того чималі зусилля витрачаються на відновлення адаптації до цивільного життя і / або ж відновлення після травми (Волошин, Марута, Шестопалова, 2014).

Раціональне ставлення щодо реабілітації після бойової травматизації проявляють близько п'ятої частини опитаних $(22,5$ \%). Вони свідомо звертаються за психотерапевтичною та медичною допомогою для відновлення психічної та психологічної цілісності. Водночас 37 \% військових, які переживають окремі симптоми травм або комплекс симптомів ПТСР, проявляють низьку готовність отримувати фахову допомогу, що так само в окремих випадках призводить до рецидивів психічних захворювань та деструктивних наслідків травматизації.

Інтенсивність стресових переживань ми дослідили за допомогою методики на визначення рівня стресу Л. Рідера (Рис. 1).

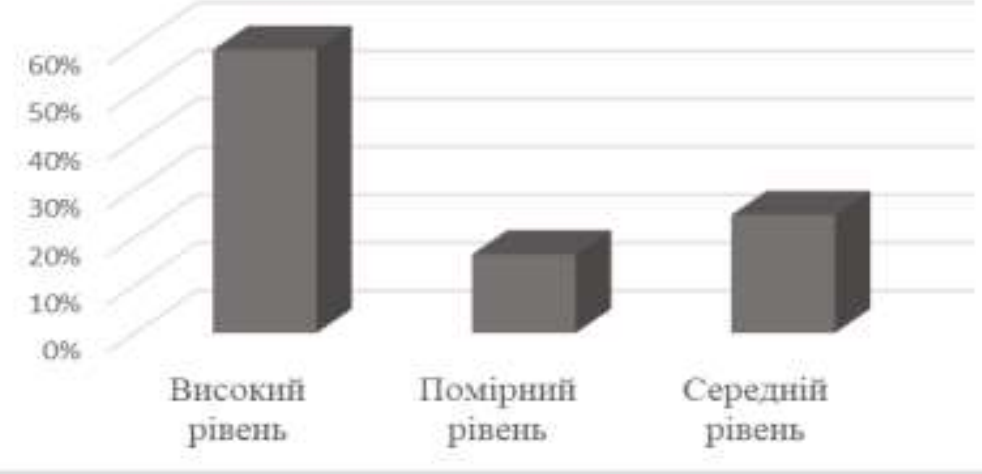
Рис. 1. Розподіл рівнів вираженості стресу у військових, учасників бойових дій ООС (у \%, N=82)


За показаними результатами у $61 \%$ опитаних військових переважає високий рівень прояву стресу, що проявляється у надпильності, мобілізаційному перенапруженні, перезбудженості та ін. Як наслідок, основними запитами для психологічної роботи $\epsilon$ потреба саморегуляції імпульсивного гніву, дратівливості та окремої симптоматики ПТСР.

За допомогою ранжування стрес-факторів військові зауважили, що однозначна перевага надається реальним ситуаціям загрози життю та фізичному здоров'ю, нестерпним є страх перед полоном та жахіття приниження честі та гідності побратимів; поранення, каліцтва та контузії; перший факт знищення супротивника; свідчення фактів жахливих сцен смерті, людських втрат і мук побратимів та мирного населення; усвідомлення помилок командування i власної безпорадності за таких умов; неочікувані зміни умов служби; контакт зі значною кількістю поранених чи мерців; далі називаються негідні умови гігієни, сексуальна дисгармонія та ін. Бойові дії загострюють духовні переживання честі та гідності особистості, цінності життя та здоров’я, актуалізують питання смислу власного життя.

Серед вагомих деструктивних наслідків бойового стресу військові називали тривалі періоди почуття смислової порожнечі та пригнічення, які ми розглядаємо в межах концепції симптоматики депресивного та субдепресивного розладу особистості (PHQ-9 шкала самооцінки депресіi) (Рис. 2).

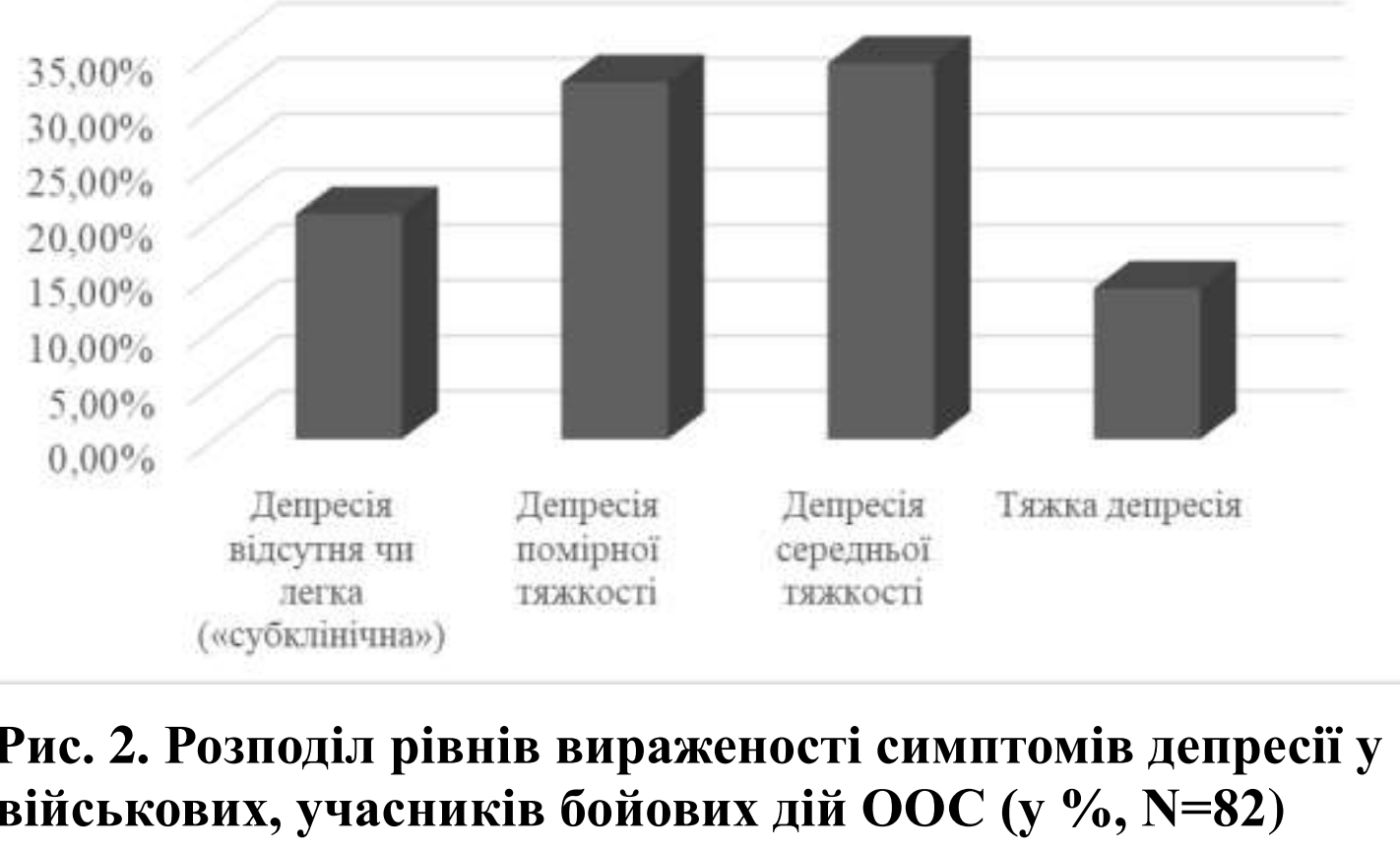


Слід констатувати, що 13,6\% військових потребують невідкладної клінічної та психотерапевтичної допомоги у зв'язку зі сталими та вираженими симптомами депресивного розладу, які часто поєднані 3 адиктивним розладом особистості. Депресивна симптоматика середньої тяжкості з періодичними загостреннями проявляється у 33,9\% опитаних військових.

Указані результати засвідчують потужність деструктивного впливу тривалого психічного страждання особистості від свідчення та участі у воєнній реальності. Психічна симптоматика певною мірою ослаблює інтенсивність страждання особистості, водночас трансформується у розлад (Голик, Ляшенко, Романишин, Романовський, 2009).

У періоди демобілізації складність адаптації до цивільного життя (зокрема й сімейного) військовослужбовців пов'язана 3 проявами запальності, ригідної поведінки та імпульсивної конфліктності (Рис. 3).

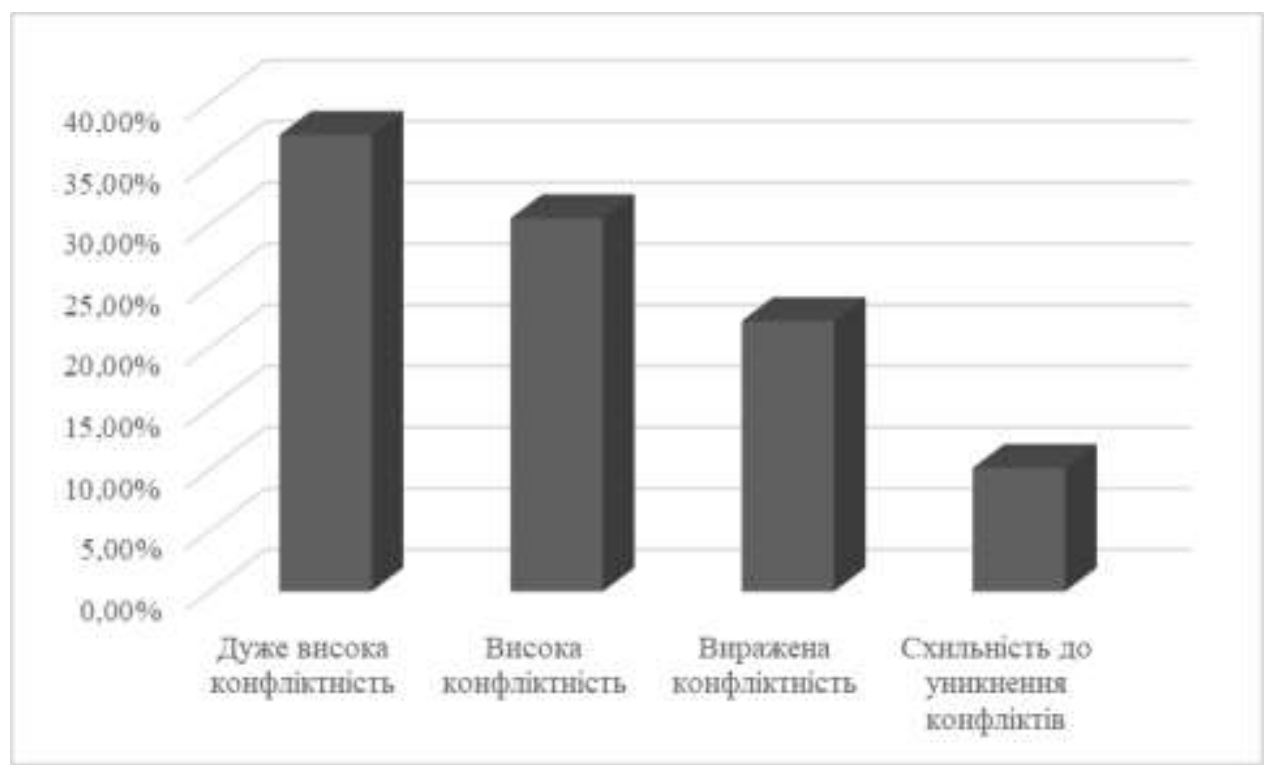

\section{Рис. 3. Розподіл рівнів вираженості конфліктності у військових, учасників бойових дій ООС (у \%, N=82)}

Схильність оперативно й агресивно реагувати в екстремальній ситуації бою формує в особистості динамічний стереотип боротьби як необхідної реакції для виживання військового у надзвичайній ситуації, натомість у цивільних умовах життя така поведінка $\epsilon$ дезадаптивною. Лише 9,76\% опитаних проявляють уникання для зниження напруги в конфліктному протиборстві, інший загал військових схильні витримувати та рішуче діяти в ситуації конфлікту, 
часто застосовуючи силові засоби боротьби. Так, $31,7 \%$ опитаних схильні до імпульсивної люті та проявів надмірної агресивності, усвідомлюють труднощі із саморегуляцією гніву. У конфліктному протиборстві такі особи схильні до інтенсивної жорстокості, що робить їх небезпечними для оточення. А $26,83 \%$ опитаних визнали, що агресія для них носить інструментальний характер, у такий спосіб особі легше заявити про себе або ж самоствердитися в певній ситуації.

Гостре відчуття небезпеки в екстремальній ситуації формує в особи надпильність та тривожний стереотип реагування. Тривога найбільш облігатний прояв гострого та хронічного стресу. Як відомо, цей стан виконує як захисну (мобілізуючу) функцію, так і дестабілізуючу у випадку, якщо ¥іi інтенсивність та тривалість перевищує індивідуальні компенсаторні можливості особистості в процесі адаптації (Приходько, 2018).

За шкалою тривожності Тейлора ми отримали такий розподіл рівнів у військових ООС (Рис. 4). Як засвідчують результати дослідження, у більшої частини військових $(65,85 \%)$ переважає високий рівень тривожності, яка в бойовій ситуації рятує їм життя, натомість у цивільному житті лягає в основу дезадаптації.

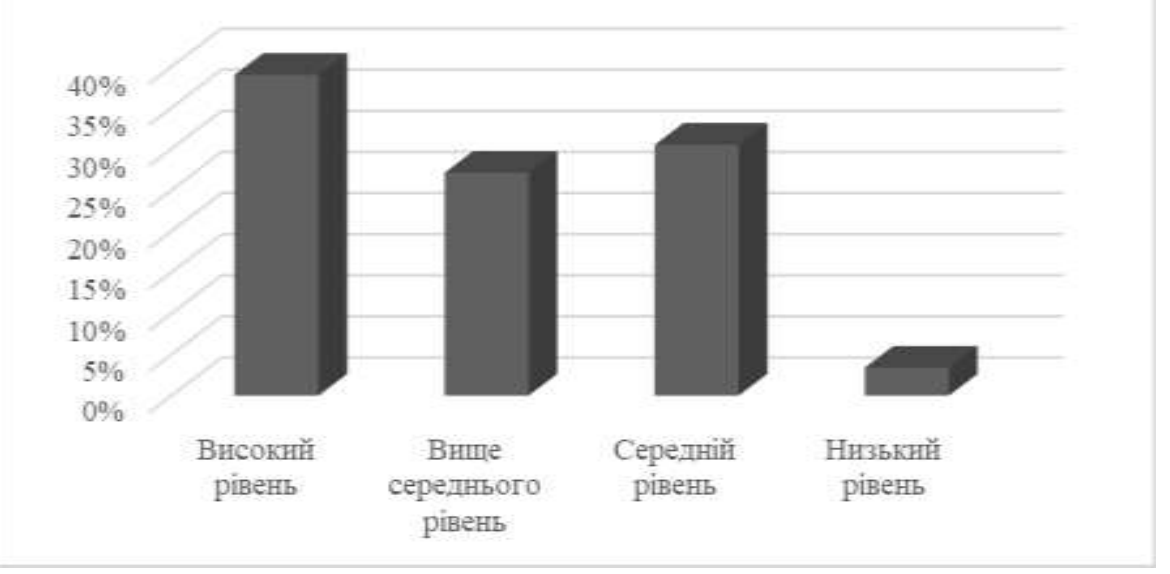

\section{Рис. 4. Розподіл рівнів тривожності у військових, учасників бойових дій ООС (y \%, N=82)}

Проаналізувавши психологічні особливості реагування демобілізованих військових, учасників бойових дій, на умови цивільного життя, ми зауважили, що поряд із сильним прагненням повернутися до мирного життя 3 родиною, військові переживають спектр фрустраційних переживань, відчай, апатію, а також ряд деструктивних особистісних змін, які формуються на тлі спотвореної, 
патологічної картини світу, динамічних поведінкових стереотипів агресивної, конфліктної поведінки. Непідготовлене, стихійне зіткнення учасника бойових дій із реаліями мирного життя може викликати повторну психотравматизацію та маніфестацію посттравматичних стресових розладів.

Висновки. Результати дослідження впливу бойового стресу на формування деструктивних станів військових показують, що у формуванні деструктивних наслідків вагому роль відіграють конфліктні переживання у системі цінностей та смислів професійної діяльності військовослужбовця, які актуалізуються в ситуації загрози життю та здоров'ю особистості. Тривалі психотравмуючі фактори бойової обстановки деструктивно впливають на емоційну сферу військових, а в силу особистісних особливостей, у багатьох демобілізованих порушується регуляція поведінки, а також моральноетична та когнітивна сфери. Негативні психічні стани, які виникають у військовослужбовців як наслідок дії бойового стресу, проявляються в реакціях некерованої агресивності, тривоги, конфліктності, апатії, що різко ускладнюють процес реадаптації демобілізованих військових та безумовно вимагають проведення психологічної корекції.

За допомогою точної оцінки та прогнозу впливу деструктивних психічних станів і переживань військового 3'являється можливість командирам частин та підрозділів спрогнозувати поведінку особового складу в екстремальних умовах та в період демобілізації для адекватного реагування на зміни в обстановці.

Результати дослідження обгрунтовують необхідність розробки нових підходів до забезпечення процесу реадаптації до мирного життя військовослужбовців за допомогою реалізації потенціалу психологічної підготовки особового складу Збройних сил України, що стане перспективою подальшого нашого дослідження.

\section{Література}

1. Блінов, О. А. (2016). Психологія бойової психічної травми: монографія, Київ.

2. Блінов, О. А. (2017). Опитувальник бойового стресу Блінова О. А. (ОБСБ). Психологічний часопис : збірник наукових прачьь за ред. С. Д. Максименка, 5(9), 32-43.

3. Волошин, П. В., Марута, Н. О., Шестопалова, Л. Ф. (2014). Діагностика, терапія та профілактика медико-психологічних наслідків бойових 
дій в сучасних умовах. Харків.

4. Голик, М. М., Ляшенко, В. М, Романишин, А. М., Романовський, Я. Я. (2009). Морально-психологічне забезпечення діяльності військ. Львів: ЛІСВ.

5. Караяни, А. Г. (2016). Настольная книга военного психолога. Москва.

6. Кравченко, К. О., Тімченко, О. В., Широбоков, Ю. М. (2017). Соціально-психологічні детермінанти виникнення бойового стресу у військовослужбовців - учасників антитерористичної операції. Харків.

7. Кудренко, О. В., Афанасенко, В. С. (2018). Вплив стрес-факторів бойової обстановки на психіку військовослужбовців повітряних сил (на основі досвіду АТО). Наука і техніка Повітряних Сил Збройних сил України, 2(31), $137-144$.

8. Локтаева, С. А. (2014). Индивидуально-типические характеристики детей в семьях кадровых военнослужащих. Вестник Московского университета, 7, 281-285.

9. Литвинцев, С. В., Снедков, Е. В., Резник, А. М. (2005). Боевая психическая травма. Москва: Медицина.

10. Осьодло, В.І. (2013). Особистісні чинники подолання стресових ситуацій в особливих умовах. Проблеми екстремальної та кризової психології, 14(1), 243-253.

11. Осьодло, В. I. (2017). Посттравматичне зростання особистості учасників бойових дій: сучасний стан та перспективи. Украӥнський психологічний журнал, 1, 63-79.

12. Приходько, I. I. (2018). Система профілактики та контролю бойового стресу у військовослужбовців. Вісник Національної академії Державної прикордонної служби України. Серія: Психологія, 1, 78-86.

13. Тополь, О.В.(2015). Соціально-психологічна реабілітація учасників антитерористичної операції. Вісник Чернігівського національного педагогічного університету, 12(4), 230-233.

14. Standard: NATO - STANAG 2409. Glossary of medical terms and definitions AMedP-13(A). Standardization agency (NSA) NATO. 6 May 2011. P. 52.

15. Shay, J. (2003). Odysseus in America: Combat Trauma and the Trials of Homecoming. New York.

\section{References}

1. Blinov, O. A. (2016). Psykholohiia boiovoi psykhichnoi travmy [Psychology of combat mental trauma]. Kyiv [in Ukrainian].

2. Blinov, O. A. (2017). Opytuvalnyk boiovoho stresu Blinova O. A. (OBSB) [Combat stress questionnaire Blinov OA (OBSB)]. Psykholohichnyi chasopys : zbirnyk naukovykh prats - Psychological Journal: a collection of scientific papers, 5 (9), 32-43 [in Ukrainian].

3. Voloshyn, P. V., Maruta, N. O., Shestopalova, L. F. (2014). Diahnostyka, terapiia ta profilaktyka medyko-psykholohichnykh naslidkiv boiovykh dii $\mathrm{v}$ suchasnykh umovakh [Diagnosis, therapy and prevention of medical and psychological consequences of hostilities in modern conditions]. Kharkiv [in 
Ukrainian].

4. Holyk, M. M., Liashenko, V. M, Romanyshyn, A. M., Romanovskyi, Ya. Ya. (2009). Moralno-psykholohichne zabezpechennia diialnosti viisk [Moral and psychological support of troops]. Lviv: LISV [in Ukrainian].

5. Karajani, A. G. (2016). Handbook of a military psychologist [Military psychologist's handbook]. Moscow [in Russian].

6. Kravchenko, K. O., Timchenko, O. V., Shyrobokov, Yu. M. (2017). Sotsialno-psykholohichni determinanty vynyknennia boiovoho stresu u viiskovosluzhbovtsiv - uchasnykiv antyterorystychnoi operatsii [Socio-psychological determinants of combat stress in servicemen - participants in the anti-terrorist operation]. Kharkiv [in Ukrainian].

7. Kudrenko, O. V., Afanasenko, V. S. (2018). Vplyv stres-faktoriv boiovoi obstanovky na psykhiku viiskovosluzhbovtsiv povitrianykh syl (na osnovi dosvidu ATO) [Influence of stress factors of a combat situation on mentality of servicemen of air forces (on the basis of experience of anti-terrorist operation)]. Nauka i tekhnika Povitrianykh Syl Zbroinykh Syl Ukrainy - Science and technology of the Air Force of the Armed Forces of Ukraine, 2 (31), 137-144 [in Ukrainian].

8. Loktaeva, S. A. (2014). Individualno-tipicheskie harakteristiki detey v semyah kadrovyih voennosluzhaschih [Individual-typical characteristics of children in the families of military personnel]. Vestnik Moskovskogo universiteta - Moscow University Bulletin, 7, 281-285 [in Russian].

9. Litvintsev, S. V., $\quad$ Snedkov, E. V., $\quad$ Reznik, A. M. (2005). Boevaya psihicheskaya travma [Combat mental trauma]. Moskva: Meditsina [in Russian].

10. Osodlo, V. I. (2013). Osobystisni chynnyky podolannia stresovykh sytuatsii v osoblyvykh umovakh [Personal factors of overcoming stressful situations in special conditions]. Problemy ekstremalnoi ta kryzovoi psykholohii - Problems of extreme and crisis psychology, 14(1), 243-253 [in Ukrainian].

11. Osodlo, V. I. (2017). Posttravmatychne zrostannia osobystosti uchasnykiv boiovykh dii: suchasnyi stan ta perspektyvy [Post-traumatic growth of the personality of combatants: current status and prospects]. Ukrainskyi psykholohichnyi zhurnal Ukrainian psychological journal, 1, 63-79 [in Ukrainian].

12. Prykhodko, I. I. (2018). Systema profilaktyky ta kontroliu boiovoho stresu $\mathrm{u}$ viiskovosluzhbovtsiv [The system of prevention and control of combat stress in servicemen]. Visnyk Natsionalnoi akademii Derzhavnoi prykordonnoi sluzhby Ukrainy. Psykholohiia - Bulletin of the National Academy of the State Border Guard Service of Ukraine. Psychology, 1, 78-86 [in Ukrainian].

13. Topol, O. V. (2015). Sotsialno-psykholohichna reabilitatsiia uchasnykiv antyterorystychnoi operatsii [Socio-psychological rehabilitation of participants in the 
anti-terrorist operation]. Visnyk Chernihivskoho natsionalnoho pedahohichnoho universytetu - Bulletin of Chernihiv National Pedagogical University, 12(4), 230-233 [in Ukrainian].

14. Standard: NATO - STANAG 2409. Glossary of medical terms and definitions AMedP-13(A). Standardization agency (NSA) NATO. 6 May 2011. R. 52. 15. Shay, J. (2003). Odysseus in America: Combat Trauma and the Trials of Homecoming. New York.

Received: 23.04 .2021

Accepted: 19.05.2021 